\title{
Strategi Dakwah Program Radio SAS FM Surabaya
}

\author{
Reny Masyitoh \\ Program Studi Komunikasi Penyiaran Islam, Fakultas Dakwah \& Komunikasi \\ Universitas Islam Negeri Sunan Ampel Surabaya, 60237, Indonesia \\ maharehny04@gmail.com
}

INFO ARTIKEL

Riwayat Artikel:

Diterima Desember 2017

Direvisi Januari 2018

Disetujui Februari 2018
ABSTRAKSI

Abstrak: Ada tiga persoalan yang dikaji dalam penelitian ini, yakni : (1) Bagaimana konsep awal terbentuknya radio SAS FM Surabaya, (2) Bagaimana strategi dakwah pada program "Ngaji Fiqih Kontemporer" dan "Tadarus Keluarga" di radio SAS FM Surabaya, (3) Bagaimana respon pendengar mengenai program "Ngaji Fiqih Kontemporer" dan "Tadarus Keluarga" di radio SAS FM Surabaya. Untuk mengungkap persoalan tersebut secara menyeluruh dan mendalam, dalam penelitian ini menggunakan penelitian kualitatif deskriptif dengan analisis induktif yang berguna untuk memberikan fakta dan data mengenai strategi dakwah program radio SAS FM. Kemudian data tersebut dianalisis dengan teori strategi programming yang diungkapkan oleh Sydney W. Head, sehingga memperoleh data yang bersifat holistik (utuh). Data dalam penelitian ini diperoleh melalui 3 cara, yakni dengan metode wawancara, observasi dan studi dokumentasi. Dari hasil penelitian ini ditemukan bahwa (1) Konsep awal terbentuknya radio SAS FM Surabaya berawal dari keinginan memperluas syiar dakwah yang ada di Masjid Nasional al-Akbar Surabaya, karena sebagai pusat dakwah. Sehingga segala kegiatan yang ada di Masjid Nasional al-Akbar Surabaya selalu disiarkan oleh radio SAS FM. (2) Strategi dakwah program "Ngaji Fiqih Kontemporer" dan "Tadarus Keluarga" di radio SAS FM Surabaya memiliki beberapa staregi, sehingga menjaikan dua program ini program unggulan, diantaranya: strategi dakwah yang pertama terletak pada Dai atau narasumber yang kompeten yang mengisi kedua program tersebut. Strategi berikutnya terletak pada waktunya siang hari, dipilih karena sangat efektif dan menjadi pembeda dengan program kajian di radio lain yang kebanyakan pagi hari. Strategi dakwah juga pada kemasan program. Program "Ngaji Fiqih Kontemporer" tidak bertopik, melainkan langsung pendengar bertanya Dai atau narasumber menjawab. Sedangkan "Tadarus Keluarga" topik terkini tentang masalah keluarga yang dipilih dan juga membahas buku yang di tulis narasumbernya. Dengan strategi inilah dapat menarik pengiklan untuk memasang iklan di radio SAS FM. (3) respon pendengar mengenai program "Ngaji Fiqih Kontemporer" dan "Tadarus Keluarga" di radio SAS FM sangat bagus, yang terletak pada Dai atau narasumber yang sangat kompeten dalam menjawab segala pertanyaan dari pendengar. Pertannyaan yang sering ditanyakan oleh pendengar dalam program "Ngaji Fiqih Kontemporer" masalah ibadah dan kehidupan seharihari. Sedangkan program "Tadarus Keluarga" pertanyaan yang sering ditanyakan tentang masalah perselingkuhan dan masalah keluarga yang lainnya. Harapan pendengar semoga ada program off air dari dua program unggulan radio SAS FM.

Abstract : There are three problems studied in this research, namely: (1) the initial concept of the formation of SAS FM radio Surabaya, (2) How to propagate strategy on the program "Ngaji Fiqih Kontemporer" and "Tadarus Keluarga" on SAS FM radio Surabaya, (3) How listeners response about the program "Ngaji Fiqih Kontemporer" and "Tadarus Keluarga" on SAS FM radio Surabaya. To solve the problem thoroughly and deeply, in this research use qualitative descriptive research with inductive analysis which is 
Kata Kunci:

Strategi Dakwah,

Program Radio,

SAS FM.

Keywords:

Da'wah Strategy,

Radio Program,

SAS FM. useful to give fact and data about strategy da'wah of SAS FM radio program. Then the data is analyzed with programming strategy theory expressed by Sydney W. Head, so as to obtain data that is holistic. The data in this research is obtained through 3 ways, namely by interview method, observation and documentation study. From the results of this study found that (1) The initial concept of the formation of SAS FM radio Surabaya originated from the desire to expand the existing da'wah syiar in National Mosque Al-Akbar Surabaya, because as the center of da'wah. So that all activities in the National Mosque al-Akbar Surabaya will always be broadcast by SAS FM radio. (2) The dakwah strategy of the program "Ngaji Fiqih Kontemporer" and "Tadarus Keluarga" in SAS FM radio Surabaya has several strategies, so that these two programs are excellent programs, among them are: the first da'wah strategy depending on Dai or competent resource person who fills both programs. The next strategy goes to in the time chosen in the daytime because it is very effective and distinguishes it from other radio programs mostly in the morning. Dakwah strategy is also on the program packaging. The program "Ngaji Fiqih Kontemporer" there are no specific topic, but listeners ask the Dai or resource person to answer directly. While "Tadarus Keluarga" is about the latest topic on selected family issues and also discuss the book written by the source person. With this strategy it can attract advertisers to advertise on SAS FM radio. (3) the response of listeners on the program "Ngaji Fiqih Kontemporer" and "Tadarus Keluarga" in SAS FM radio is very good, because handled by Dai or a highly competent resource person in answering questions from the listener. Questions often asked by listeners in the program "Ngaji Fiqih Kontemporer" are about the problem of worship and daily life. While the frequently asked questions in "Tadarus Keluarga" program are about infidelity and other family problems. Listeners hope it may have off air programs from two excellent radio program SAS FM.

\section{Pendahuluan}

Perkembangan media komunikasi modern saat ini telah memungkinkan orang diseluruh dunia untuk dapat saling berkomunikasi. Hal ini dimungkinkan karena adanya berbagai media yang dapat digunakan sebagai sarana penyampaian pesan. Media penyiaran, yang salah satunya adalah radio merupakan salah satu bentuk media massa yang efisien dalam mencapai audiennya dalam jumlah yang sangat banyak karena media penyiaran memegang peranan yang sangat penting dalam ilmu komunikasi pada umumnya dan khususnya ilmu komunikasi penyiaran.

Radio siaran merupakan salah satu jenis media massa, yakni sarana atau saluran komunikasi massa, seperti halnya surat kabar, majalah, atau televisi. ${ }^{1}$ Radio sebagai media massa memiliki warna tersendiri bagi pendengarnya yang ingin mendapatkan informasi dan pemenuhan keinginan pendengar.

Tingkat persaingan stasiun radio di kota-kota besar dewasa ini cukup tinggi dalam merebut perhatian audiens. Program radio harus dikemas sedemikian rupa agar menarik perhatian dan dapat diikuti sebanyak mungkin orang. Jumlah stasiun radio yang semakin banyak mengharuskan pengelola stasiun untuk semakin jeli membidik audiennya. ${ }^{2}$

Persaingan antar media massa ini tidak terlepas dari fungsinya yaitu informasi, pendidikan, dan hiburan. Dengan banyak memperhatikan sinyalemen mengenai massa depan, serta masyarakat umum yang hendak mempersiapkan diri dalam menghadapi komunikasi global, maka dalam pemanfaatannya media massa harus mempertimbangkan banyak hal. Salah satunya adalah kemajuan era digital saat ini dan yang akan datang. 
Radio merupakan media auditif, tetapi murah, merakyat dan bisa dibawa atau didengarkan di mana-mana. Radio memiliki kekuatan terbesar sebagai media imajinasi, sebab sebagai media yang buta, radio menstimulasi begitu banyak suara, dan berupaya menvisualisasikan suara penyiar ataupun informasi faktual melalui telinga pendengar. ${ }^{3}$

Radio merupakan salah satu media elektronik yang digunakan oleh masyarakat sebagai alat atau media informasi sebelum adanya televisi. peran radio sangat penting karena radio memberikan informasi berupa berita, hiburan, media berekspresi, media pendidikan, bahkan tempat beriklan suatu produk atau jasa perusahaan. Radio adalah media audio yang hanya bisa dinikmati khalayak dengan cara mendengarkan.

Pendengar radio bukan lagi obyek yang menggunakan telinga untuk menyimak sebuah acara. Mereka juga menggunakan nalar pikir dan sekaligus empati, sehingga membentuk sikap kritis. Jika program yang ditayangkan radio tidak sesuai, maka sikap mereka tidak sekedar memindah channel atau gelombang ke stasiun lain, tetapi akan bersikap antipati terhadap stasiun yang dinilai mengecewakan. ${ }^{4}$

Program yang dimiliki oleh stasiun radio menjadikan pendengar merasa memiliki kemudahan dalam memenuhi kebutuhan yang mereka inginkan. Salah satu program yang hampir dimiliki oleh semua stasiun radio adalah program dakwah Islam. Radio memiliki fungsi sebagai media pendidikan, dakwah termasuk di dalamnya yakni memberikan pendidikan tentang pemahaman agama Islam bagi pendengarnya. Kini radio pun dapat dijadikan sebagai media dakwah bagi siapa saja yang ingin menyampaikan pesan-pesan kebaikan untuk seluruh pendengar.

Dakwah dapat dilakukan melalui berbagai cara, tidak hanya melalui lisan, tetapi juga bisa dilakukan melalui media komunikasi. Seperti radio, televisi, film, dan juga media komunikasi lainnya. Jika ditinjau dari komunikasi, dakwah merupakan proses penyampaian pesan-pesan (message) berupa ajaran Islam yang disampaikan secara persuasiv (hikmah) dengan harapan agar komunikan (mad'u) dapat bersikap dan berbuat amal shaleh sesuai dengan ajaran Islam.

Radio sebagai media penyiaran juga mengalami perkembangan, hingga terbentuklah beberapa radio swasta yang bernuansa Islami. Radio Suara Akbar Surabaya (SAS) FM yang memiliki slogan Radio Inspirasi Muslim Sejuk Bermakna, merupakan salah satu radio Islami yang berada di kompleks Masjid Nasional al-Akbar Surabaya. Terdiri dari format siaran news, music, knowledge, inspiration and motivation. Radio SAS FM memiliki visi sebagai media pengembangan syiar, dengan mengedepankan aspek informasi yang menyejukkan serta memiliki makna bagi para pendengar, khususnya umat muslim.

Program yang dimiliki radio SAS FM lebih banyak menyiarkan program-program Islami. Menginggat radio SAS FM sebagai radio penyalur kegiatan-kegiatan atau kajian-kajian yang ada di Masjid Nasional al-Akbara Surabaya, sehingga radio ini lebih banyak program Islaminya.

Radio SAS FM Surabaya hadir memberikan warna siaran yang menyejukkan dan penuh makna dengan mengunggulkan program yang dimilikinya. Program di radio SAS FM memiliki keanekaragaman, mulai dari kajian live dari Masjid Nasional al-Akbar Surabaya, dialog keluarga, psikologi anak, motivasi, kesehatan dan ekonomi. Namun ada beberapa program Islami yang menjadi unggulan, seperti program Keluarga Sakinah, Tadarus Keluarga, Ngaji Fiqih Kontemporer, Tadabar (tanya jawab akbar), kajian fajar dan kajian senja yang disisrkan secara langsung dari ruang utama Masjid Nasional al-Akbar Surabaya. Program unggulan ini terlihat dari banyaknya pendengar yang bergabung melalui SMS, Telepon, Facebook, Tweeter dan pendengar yang mendengarkan melalui streaming. Kemudahan untuk bergabung atau bertanya dan mendapatkan penjelasan dari narasumber merupakan keinginan dari para pendengar. Tanpa harus 
bertatap muka, kapanpun dan dimanapun tetap dapat penjelasan dan ilmu yang dibutuhkan oleh siapapun terkait masalah kehidupan sehari-hari.

Berdasarkan hal tersebut di atas, maka peneliti mengangkat permasalahan ini kedalam sebuah penelitian dengan judul : Strategi Dakwah Program Radio SAS FM Surabaya.

Adapun identifikasi dan batasan masalah dari penelitian ini adalah kemudahan untuk mendapatkan informasi dan ilmu melalui radio merupakan kebutuhan masyarakat, terlebih ilmuilmu agama. Masalah yang sering dihadapi oleh masyarakat adalah masalah-masalah seputar keluarga, ibadah, sosial dan lain-lain, yang sesuai dengan perkembangan masalah saat ini. Dan respon dari pendengar juga dibutuhkan oleh manajemen radio sebagai ukuran kesuksesan suatu program acara. Maka keberadaan siaran dakwah melalui radio dirasakan makin penting dan diharapkan bisa menjawab dan merespon persoalan yang timbul di masyarakat.

Pembatasan masalah penelitian ini berfokus pada penjelasan atau uraian tentang konsep awal terbentuknya radio SAS FM Surabaya, bagaimana strategi dakwah pada program "Ngaji Fiqih Kontemporer" dan "Tadarus Keluarga" di radio SAS FM Surabaya, serta respon pendengar mengenai program "Ngaji Fiqih Kontemporer" dan "Tadarus Keluarga" yang dimiliki oleh radio SAS FM Surabaya.

Rumusan Masalah dalam penelitian ini adalah : 1) Bagaimana konsep awal terbentuknya radio SAS FM Surabaya? 2) Bagaimana strategi dakwah pada program "Ngaji Fiqih Kontemporer" dan "Tadarus Keluarga" di radio SAS FM Surabaya? 3) Bagaimana respon pendengar mengenai program "Ngaji Fiqih Kontemporer" dan "Tadarus Keluarga" di radio SAS FM Surabaya?

Sedangkan tujuan dari penelitian ini adalah 1) Untuk mengetahui konsep awal terbentuknya radio SAS FM Surabaya. 2) Untuk mengetahui strategi dakwah pada program "Ngaji Fiqih Kontemporer" dan "Tadarus Keluarga" di radio SAS FM Surabaya. 3) Untuk mengetahui respon pendengar mengenai program "Ngaji Fiqih Kontemporer" dan "Tadarus Keluarga" di radio SAS FM Surabaya

Penelitian ini juga memiiki kegunaan penelitian, yaitu secara teoritis Penelitian ini diharapkan mampu menambah khasanah keilmuan tentang Ilmu komunikasi terutama komunikasi yang dilakukan melalui media elektronik (radio) dan juga bisa menambah pengetahuan tentang proses pelaksanaan dakwah melalui media radio, dan Memadukan antara teori komunikasi dan religiuitas dalam pelaksanaan dakwah, mengembangkan serta membentuk pola komunikasi yang dilakukan oleh dai dalam penyampaian dakwahnya melalui radio.

Adapun kegunaan penelitian secara praktis yaitu Penelitian ini diharapkan mampu menjadi pedoman bagi para da'i dalam melakukan komunikasi melalui media radio dalam hal ini komunikasi yang dilakukan dalam bentuk dakwah, dan . Menjadi pijakan bagi para Dai, mad'u dan masyarakat muslim pada umumya dalam upaya pelaksanaan dakwah melalui media radio.

Secara umum penelitian ini bisa berguna bagi agama Islam khususnya dunia dakwah, seorang Dai yang melakukan aktivitas dakwah melalui media radio bisa benar-benar melakukannya dengan baik dan terkonsep sehinga masyarakat dapat menerima dakwah yang dilakukan melalui media radio. Selain itu, manfaat hasil penelitian ini dapat digunakan sebagai pembanding bagi peneliti lain dalam pengkajian dakwah melalui media radio

\section{Kajian Pustaka}

\section{A. Tinjauan Pustaka tentang Strategi Dakwah}

Strategi dalam segala hal digunakan untuk mencapai tujuan yang telah ditetapkan. ${ }^{5}$ Tujuan tidak akan mudah dicapai tanpa strategi, karena pada dasarnya segala tindakan atau perbuatan itu 
tidak lepas dari strategi. Strategi yang disusun, dikonsentrasikan dan dikonsepsikan dengan baik dapat membuahkan pelaksanaan yang disebut strategis. Menurut Hisyam Alie, ${ }^{6}$ untuk mencapai strategi yang strategis harus memperhatikan hal-hal sebagai berikut: a) Strength (Kekuatan), yakni memperhitungkan kekuatan yang dimiliki yang biasanya menyangkut manusia, dana, dan beberapa piranti yang dimilikinya. b) Weakness (Kelemahan), yakni memperhitungkan kelemahan-kelemahan yang dimilikinya, yang menyangkut aspek-aspek sebagaimana dimiliki kekuatan. c) Opportunity (Peluang), yakni seberapa besar peluang yang mungkin tersedia di luar, hingga peluang yang sangat kecil sekalipun dapat diterobos. d) Threats (Ancaman), yakni memperhitungkan kemungkinan adanya ancaman dari luar.

Jadi strategi adalah proses penentuan rencana para pemimpin puncak yang berfokus pada tujuan jangka panjang organisasi, disertai penyusunan suatu cara atau upaya bagaimana agar tujuan tersebut dapat dicapai.

Sedangkan dakwah adalah proses merealisasikan ajaran Islam dalam dataran kehidupan manusia dengan strategi, metodologi, dan sistem dengan mempertimbangkan dimensi religiososio-psikologis individu atau masyarakat agar target maksimalnya tercapai. ${ }^{7}$

Strategi dakwah adalah perencanaan yang berisi rangkaian kegiatan yang didesain untuk mencapai tujuan dakwah tertentu. Ada dua hal yang perlu diperhatikan dalam hal ini, yaitu: a) Strategi merupakan rencana tindakan (rangkaian kegiatan dakwah) termasuk penggunaan metode dan pemanfaatan berbagai sumber daya atau kekuatan. Dengan demikian strategi merupakan proses penyusunan rencana kerja, belum sampai pada tindakan.

b) Strategi disusun untuk mencapai tujuan tertentu. Artinya, arah dari semua keputusan penyusunan strategi adalah pencapaian tujuan. Oleh sebab itu, sebelum menentukan strategi, perlu dirumuskan tujuan yang jelas serta dapat diukur keberhsilannya.

Tujuan dakwah dapat dibagi menjadi dua macam, yaitu tujuan utama dan tujuan khusus. Tujuan utama merupakan garis pokok yang menjadi arah semua kegiatan dakwah, yaitu perubahan sikap dan perilaku mitra dakwah sesuai dengan ajaran Islam. Tujuan khusus harus realistis, konkret, jelas, dan bisa diukur. Selain itu tujuan khusus juga berisi beberapa tahapan. Tujuan dakwah itulah yang dijadikan dasar penyusunan strategi dakwah dengan memperhatikan masing-masing tujuan khusus.

Dalam kegiatan komunikasi, mengartikan strategi sebagai perencanaan (planning) dan manajemen (management) untuk mencapai suatu tujuan. Tidak hanya berfungsi sebagai peta jalan yang harus ditempuh, tetapi juga berisi taktik operasionalnya, serta harus didukung oleh teori karena teori merupakan pengetahuan berdasarkan pengalaman yang sudah diuji kebenarannya. Untuk strategi komunikasi tersebut, segala sesuatunya harus memerhatikan komponen komunikasi dalam teori Harold D. Lassell, yaitu Who says What in Which Channel to Whom with What effect (komunikator, pesan, media, komunikan, dan efek).

Setiap strategi membutuhkan perencanaan yang matang. Dalam dakwah kelembagaan, perencanaan yang strategis paling tidak berisi analisis SWOT yaitu Strength (keunggulan), Weakness (kelemahan), Opportunity (peluang), dan Threat (ancaman) yang dimiliki atau dihadapi organisasi dakwah.

Strategi dakwah membutuhkan penyesuaian yang tepat, yakni dengan memperkecil kelemahan dan ancaman serta memperbesar keunggulan dan peluang. Pola penyesuaian ini disebutkan oleh M. Natsir sebagai dakwah bi al-hikmah (dakwah dengan bijaksana) antara lain: ${ }^{8}$ a) Bijak dalam mengenal golongan. b) Bijak dalam memilih saat harus bicara dan saat harus diam. c) Bijak dalam mengadakan kontak pemikiran dan mencari titik pertemuan sebagai tempat bertolak untuk maju 
secara sistematis. d) Bijak tidak melepaskan shibghah. e) Bijak memilih dan menyusun kata yang tepat. f) Bijak dalam cara perpisahan. Bijak dengan arti keteladanan yang baik (uswah hasanah dan lisan al-hal)

\section{B. Tinjauan Pustaka tentang Program Radio}

Kata program berasal dari bahasa Inggris programme atau program yang berarti acara atau rencana. Undang-Undang Penyiaran Indonesia tidak menggunakan kata program untuk acara tetapi menggunakan istilah "siaran" yang didefinisikan sebagai pesan atau rangkaian pesan yang disajikan dalam berbagai bentuk. Namun kata program lebih sering digunakan dalam dunia penyiaran di Indonesia dari pada kata siaran untuk mengacu kepada pengertian acara. Program adalah segala hal yang ditampilkan stasiun penyiaran untuk memenuhi kebutuhan audiennya.

Program atau acara yang disajikan adalah faktor yang membuat audien tertarik untuk mengikuti siaran yang dipancarkan stasiun penyiaran radio atau televisi. Program dapat disamakan atau dianalogikan dengan produk atau barang atau pelayanan yang dijual kepada pihak lain, dalam hal ini audien dan pemasang iklan. Dengan demikian, program adalah produk yang dibutuhkan orang sehingga mereka bersedia mengikutinya.

Program radio SAS FM adalah acara- acara yang disiarkan oleh radio SAS FM seperti: Kajian Fajar, Wadduha, Syair dan Syiar Pagi, Jeda Siang, Keluarga Sakinah, Ngaji Fiqih Kontemporer, Dialog Kesehatan, SAS Info Terkini, Tajabar, Curhat Bersama Bunda, Kajian Tafsir, Anatomi alQur'an, Indahnya Sholat Kajian Senja, dan Dialog Malam. Program yang akan dijadikan penelitian dalam penelitian ini adalah "Ngaji Fiqih Kontemporer" dan "Tadarus Keluarga"

\section{Radio sebagai Media Dakwah}

Sudah menjadi komitmen bahwa setiap muslim wajib memanggul tanggung jawab mulia untuk berdakwah atau menjadi pendakwah, artinya setiap muslim bertugas dan berkewajiban mengajak dan menyeru umat manusia agar bersedia menerima dan memeluk agama Islam, dalam bentuk amar ma'ruf nahi munkar, yang tujuannya adalah terwujudnya kebahagiaan dan kesejahteraan hidup di dunia dan akhirat yang diridhai oleh Allah SWT.

Sedangkan Media dakwah adalah peralatan yang dipergunakan untuk menyampaikan pesan dakwah. Dalam arti sempit media dakwah dapat diartikan sebagai alat yang digunakan untuk menyampaikan ajaran Islam kepada umat. ${ }^{9}$ Sedangkan menurut Hamzah Tualeka, media dakwah adalah perantara atau penghubung yang diperlukan agar materi dakwah yang diberikan juru dakwah dapat diterima, diresapi dan diamalkan oleh umat yang menjadi obyek dakwahnya. ${ }^{10}$

Setidak-tidaknya ada empat indikasi yang menegaskan fungsi radio sebagai media komunikasi massa, dalam hal ini yang berfungsi sebagi media sosial kemasyarakatan. Pertama, radio sebagai media penyampaian informasi dari satu pihak ke pihak lain. Kedua, radio sebagai sarana mobilitas pendapat publik untuk mempengaruhi kebijakan. Ketiga, radio sebagai sarana untuk mempertemukan dua pendapat berbeda atau diskusi untuk mencari solusi bersama yang saling menguntungkan. Keempat, radio sebagai sarana untuk mengikat suatu kebersamaan dalam semangat kemanusiaan dan kejujuran. ${ }^{11}$

\section{Kelebihan dan Kelemahan Radio sebagai Media Dakwah}

Kelebihan media radio sebagai wasilah dakwah adalah: ${ }^{12}$

1. Bersifat langsung, Untuk menyampaikan dakwah melalui radio, tidak harus melalui proses yang kompleks sebagaimana penyampaian materi dakwah lewat pers, Majalah umpamanya. 
Dengan mempersiapkan secarik kertas. Dai dapat secara langsung menyampaikan dakwah di depan mikrofon.

2. Siaran radio tidak mengenal jarak dan rintangan, Faktor lain yang menyebabkan radio dianggap memiliki kekuasaan ialah, siaran radio tidak mengenal jarak dan rintangan selain waktu, ruangpun bagi radio siaran tidak merupakan masalah, bagaimanapun jauhnya sasaran yang dituju. Daerah-daerah terpencil yang sulit dijangkau dakwah dengan media lain dapat diatasi dengan wasilah radio ini.

3. Radio siaran mempunyai daya tarik yang kuat, Faktor lain yang menyebabkan radio memiliki kekuasaan adalah daya tarik yang kuat yang dimilikinya. Daya tarik ini ialah disebabkan sifatnya yang serba hidup berkat tiga unsur yang ada padanya, yakni musik, katakata dan efek suara.

4. Biaya yang relatif murah, Radio pada umumnya telah menjadi media utama yang dimiliki oleh setiap penduduk, baik yang kaya maupun yang miskin. Bedanya yang kaya mungkin mempunyai seperangkat radio sterio yang canggih, sedangkan yang miskin hanya memiliki radio transitor.

5. Mampu menjangkau tempat-tempat terpencil, Dibeberapa Negara, radio bahkan merupakan satu-satunya alat komunikasi yang efektif untuk menghubungi tempat-tempat terpencil.

6. Tidak terhambat oleh kemampuan baca dan tulis, Siaran radio tidak terhambat oleh kemampuan baca dan tulis khalayak. Dibeberapa Negara Asia tingkat kemampuan baca dan tulis populasinya lebih dari $60 \%$. Jutaan orang tersebut tidak disentuh oleh media massa lain kecuali bahasa radio dalam bahasa mereka.

Sedangkan kelemahan radio ialah: ${ }^{13}$

1) Selintas. Siaran radio cepat hilang dan gampang dilupakan. Pendengar tidak biasa mengulang apa yang didengarnya, tidak bisa seperti pembaca Koran yang bisa mengulang bacaannya dari awal tulisan. 2) Global. Sajian informasi radio bersifat global, tidak detail, karena angka-angkapun dibulatkan. 3) Batas waktu. Waktu siaran radio relatif terbatas, hanya 24 jam sehari, berbeda dengan Surat Kabar yang bisa menambah jumlah halaman dengan bebas. 4) Beralur linier. Program disajikan dan dinikmati pendengar berdasarkan urutan yang sudah ada, tidak bisa meloncat-loncat. Beda dengan Surat Kabar, pembaca bisa langsung ke halaman tengah, akhir, atau langsung ke rublik yang ia suka. 5) Mengandung gangguan. Saat mendengarkan program acara radio, pendengar terkadang mengalami gangguan secara teknis.

\section{E. Manajemen Siaran Radio}

Media penyiaran dan juga perusahaan lainnya pada umumnya posisi manajer biasanya terdiri atas tiga tingkatan yaitu: 1) Manajer tingkat bawah. Manjer pada tingkat ini bertugas mengawasi secara dekat pekerjaan rutin karyawan yang berada di bawah naungannya. Pada stasiun radio, manajer tingkat bawah adalah seorang manajer penjualan lokal yang bertanggung jawab kepada manajer penjualan umum atau pada stasiun televisi, seorang manajer produksi bertanggung jawab kepada manajer program.

2) Manajer tingkat menengah. Bertanggung jawab untuk melaksanakan kegiatan tertentu sebagai bagian dari proses untuk mencapai tujuan utama perusahaan. Manajemen menengah dapat meliputi beberapa tingkatan dalam suatu organisasi. Para manajer menengah membawahi dan mengarahkan kegiatan-kegiatan para manajer lainnya dan kadang-kadang juga karyawan operasional. Sebutan lain bagi manajer menengah adalah manajer departemen, kepala pengawas dan sebaginya.

3) Manajer puncak. Manajer yang mengoordinasikan kegiatan perusahaan serta memberikan arahan dan petunjuk umum untuk mencapai tujuan perusahaan. Klasifikasi manajer tertinggi ini 
terdiri dari sekelompok kecil eksekutif. Manajemen puncak bertanggung jawab atas keseluruhan manajemen organisasi. Sebutan khas bagi manajer puncak adalah direktur atau presiden direktur.

\section{Kajian Teoritik}

Setiap penelitian selalu menggunakan teori. Kerlinger (1978) mengemukakan teori adalah seperangkat konstruk (konsep), definisi dan proposisi yang berfungsi untuk melihat fenomena secara sistematik, melalui spesifikasi hubungan antar variabel, sehingga dapat berguna untuk menjelaskan dan meramalkan fenomena. ${ }^{14}$

Teori adalah seperangkat dalil atau perinsip umum yang kait mengait mengenai aspek-aspek suatu realitas. ${ }^{15}$ Sedangkan fungsi teori adalah menerangkap, meramalkan atau memprediksi dan menemukan keterpautan fakta-fakta secara sistematis.

Kerangka teori ini dimaksudkan untuk memberikan gambaran atau batasan-batasan teori yang dipakai sebagai landasan penelitian yang dilakukan. Dalam penelitian ini, peneliti menggunakan teori strategi programming yang diungkapkan oleh Sydney W. Head mencakup lima elemen, yaitu: ${ }^{16}$ Compatibility (kesesuaian), Radio siaran harus membuat program-program acara yang sesuai dengan kegiatan sehari-hari pendengar yang berbeda-beda dalam setiap waktu. Hal tersebut dapat dilakukan dengan cara penjadwalan program acara yang berbeda jenis dan isinya untuk menyesuaikan situasi dan kondisi yang dialami pendengar.

Habit formation (membangun kebiasaan), Semakin lama waktu pendengar mengikuti program, maka akan berdampak pada lamanya pemasang iklan untuk melakukan promosi. Selain itu juga dapat berfungsi sebagi acuan dalam merencanakan program-program acara baru yang akan dibuat. Oleh karena itu masing-masing radio siaran harus dapat membangun kebiasaan mendengarkan target pendnegarnya. Dapat dilakukan dengan cara menyiarkan program acara serupa secara live setiap harinya (strip programming), untuk memperbanyak jumlah perolehan pendengar.

Control of audience flow (mengontrol aliran pendengar), Artinya, berusaha untuk memaksimalkan jumlah pendengar yang mendengarkan dan meminimalisir jumlah pendengar yang berpindah gelombang ke radio siaran lain. Dapat dilakukan dengan metode countering (menyajikan program acara yang berbeda dengan radio siaran lain) atau menggunakan metode blunting (menyajikan program acara serupa atau mirip dengan radio siaran lain).

Conservation of program resource (pemeliharaan sumber daya program), Siaran yang dilakukan harus berjalan terus menerus sepanjang hari, maka ketersediaan materi dan sumber daya lainnya yang mendukung program harus benar-benar diperhitungkan. Berbagai upaya harus dilakukan agar materi yang terbatas dapat digunakan sebagi bahan siaran sepanjang hari, misalnya dengan mengemas ulang suatu materi dengan menggunakan pendekatan dan cara penyajian yang berbeda.

Bredth of appeal (daya tarik yang luas), Radio siaran harus memperhatikan perbedaan minat dan kesukaan dari pada pendengarnya. Sehingga harus diupayakan program-program acara yang menerik, serta dapat mengakomodir semua keinginan dan kesukaan pendengar.

Seorang programmer selain memiliki kemampuan untuk merencanakan program, juga perlu memahami fungsi program yang diintegrasikan dengan pengetahuan perkembangan penyiar radio. Seorang programmer paling tidak mempunyai enam fungsi dibawah ini: ${ }^{17}$

14 Sugiyono, Memahami Penelitian Kualitatif (Bandung: Alfabeta, 2005), 41

15 Onong Uchjana Effendy, Ilmu teori dan Filsafat Komunikasi (Bandung: Citra Aditya Bakti, 2003), 244.

16 Sydney W. Head, Broadcasting in America: a Survey of Television, Radio and New Technologies (Houghton Mifflin Company, Dallas, 1982), 10.

17 Harley Prayudha, Radio: Suatu Pengantar Untuk Wacana dan Praktek penyiaran (Malang: Bayumedia Publishing, 2004$), 44$. 
Fungsi programming memang sangat sulit jika dikaji dari ukuran keakuratannya (difficult to size accurately). Operasional penyiaran radio komersial di Indonesia memiliki perencanaan penjadwalan program untuk setiap harinya dalam seminggu 15 sampai 20 jam sehari. Tidak sedikit pula yang memiliki penjadwalan tanpa henti atau 24 jam setiap hari.

Berkesinambungan (continous). Stasiun penyiaran radio dalam melakukan siarannya tidak hanya dengan satu atau dua program saja, sejak "sig one" di pagi hari, tanpa berhenti hingga "sig off'. Tinjauan fungsi keseimbangan ini secara nyata adalah untuk mengembangkan jumlah pendnegar dari hari ke hari. Kebiasaan pendengar adalah jika suatu program mereka suka, maka dijamin akan terus mendengar program tersebut hingga tuntas. Dan sebaliknya jika tidak suka mereka akan pindah meninggalkan program tersebut untuk mencari stasiun penyiaran radio lain.

Persaingan yang luar biasa (extremely competitive). Banyak stasiun penyiaran radio yang membidik dengan target pendengar yang sama, karena jumlah radio saat ini semakin banyak. Selain itu persaingan tidak saja ditingkatkan stasiun yang berdiri sendiri (single station) tetapi sudah sampai ditingkat jaringan (networks). Oleh karena itu para pengelola stasiun penyiaran radio harus terus berupaya agar program-program yang disajikan terdengar berbeda untuk menjadi program unggulan dan disukai oleh pendengarnya. Kreatifitas menjadi hal penting dalam memenangkan persaingan ini.

Menjaga stabilitas dalam jadwal program. Hal ini merupakan upaya untuk mengembangkan kebiasaan mendengarkan. Semakin lama waktu pendengar mengikuti program, maka akan berdampak kepada lamanya pemasang iklan melakukan promosi. Selain itu juaga berfungsi untuk menjadi acuan dalam merencanakan program-program baru yang akan dibuat.

Mencari dan memperoleh ide dan materi kreatif, yang bisa didapat dari berbagai sumber yang memungkinkan. Hal ini penting karena harus berfungsi untuk mengembangkan ide-ide, bentuk program baru, dan memelihara imajinasi pendengar.

Fungsi spekulasi yang sangat tinggi (highly speculative). Tidak ada aturan pasti untuk memprediksikan ide program akan berhasil dan diminati pendengar. Jika kegagala program sudah bisa diprediksi, boleh jadi hal ini akan mempermuda penataan acara, yang dalam kenyataannya kegagalan itu tidak bisa dikemukakan.

Kelima strategi tersebut sering digunakan dalam penyusunan program pada media radio dan juga televisi. Strategi programming dalam media radio, digunakan agar program yang disiarkan dapat menarik pendengar. Dengan memperhatikan lima strategi programming ini maka suatu program dalam radio dapat memiliki kualitas program yang baik, serta dapat menjadikan sumber daya manusia yang memiliki kompetensi dan semangat dalam mengembangkan kreativitas suatu program.

Seorang programmer memiliki peran yang sangat besar dalam suatu program yang akan disiarkan. Kekuatan besar terdapat dalam program yang disiarkan oleh radio. Dari keunggulan dan kualitas yang baik serta ada pembeda dengan program yang lainnya, maka dapat menarik banyaknya iklan.

\section{Metode Penelitian}

\section{A. Rancangan dan Jenis Penelitian}

Di lihat dari pendekatannya, penelitian ini menggunakan penelitian kualitatif. Karena penelitian ini berakar pada latar alamiah sebagai keutuhan, mengandalkan manusia sebagai instrument pengumpul data, mengandalkan analisis data secara induktif, mengarah pada penemuan teori, bersifat deskriptif, lebih mementingkan proses daripada hasil, membatasi studi 
dengan fokus, memiliki kriteria untuk memeriksa keabsahan data, rancangannya bersifat sementara dan kesimpulan penelitian disepakati oleh peneliti dan subyek yang diteliti. ${ }^{18}$

Metode kualitatif mengaharuskan peneliti menganalisis topik kajiannya melalui alat bantu pemahaman seperti cerita, mitos ataupun tema. Sehingga dalam penelitian ini, peneliti berusaha menggali cerita-cerita yang berkaitan dengan strategi dakwah program radio SAS FM Surabaya selama masa penelitian yang telah dijadwalkan.

Jadi hal pertama yang harus peneliti miliki untuk memulai penelitian ini adalah sifat yang reseptif, yaitu sifat yang selalu mencari dan bukan menguji. Selain itu peneliti juga harus memiliki kekuatan integrative, yakni suatu kekuatan untuk memadukan berbagai macam informasi yang diterima menjadi satu kesatuan penafsiran. ${ }^{19}$

Sedangkan jenis penelitian yang digunakan dalam penelitian ini adalah jenis penelitian deskriptif. Jenis penelitian deskriptif yaitu prosedur penelitian yang menghasilkan data deskriptif berupa kata-kata tertulis atau lisan dari orang-orang dan perilaku yang diamati kemudian diarahkan pada suat latar dan individu secara holistic (utuh).

Adapun alasan mengapa penulis memilih jenis penelitian deskriptif karena obyek penelitian merupakan suatu fenomena dalam suatu komunitas yang memiliki karakter yang heterogen, sehingga dengan metode ini lebih cepat menyesuaikan dengan banyak pengaruh nilai-nilai yang diharapkan dan data yang diperoleh akan lebih aktual dan obyektif serta lebih memudahkan peneliti dalam berinteraksi dengan responden.

\section{B. Subjek dan Lokasi Penelitian}

Sesuai dengan judul tesis "Strategi Dakwah Program Radio SAS FM Surabaya" maka yang menjadi subyek penelitian adalah orang-orang yang terlibat dalam pemprograman dan penyiaran di radio SAS FM yakni station manager, manager siaran \& produksi, dan produser program, serta beberapa pendengar program "Ngaji Fiqih Kontemporer" dan "Tadarus Keluarga”.

Adapun lokasi penelitian ini adalah radio SAS FM Surabaya yang beralamatkan di kompleks Masjid Nasional Al-Akbar Surabaya, jalan MAS Timur 1 Pagesangan Surabaya.

\section{Jenis dan Sumber Data}

Jenis data yang digunakan dalam penelitian ini adalah data primer dan data sekunder. Data primer adalah data yang diperoleh langsung dari sumbernya, diamati dan dicatat untuk pertama kali. Dalam pengumpulan data primer dapat dilakukan dengan menggunakan cara wawancara. Dalam hal ini peneliti mendapatkan data yang diperoleh dari wawancara dengan orang-orang yang terlibat dalam pemprograman dan penyiaran di radio SAS FM Surabaya.

Data sekunder adalah data yang diperoleh peneliti sendiri. Data sekunder biasanya berwujud data dokumentasi atau data laporan yang telah tersedia. Dalam hal ini peneliti mendapatkan data yang diperoleh dari radio SAS FM Surabaya, seperti dokumen pribadi yang dimiliki SAS FM melaui bagian administrasi.

Untuk kelengkapan jenis data diatas maka diperlukan adanya sumber data yang dipakai peneliti untuk melengkapi jenis data tersebut, yaitu:

Dalam penelitian ini dipilih station manager, manager siaran\&produksi, dan produser program untuk mendapatkan data yang berhubungan dengan radio SAS FM Surabaya. Pemilihan informan dari pendengar dalam penelitian ini adalah pendengar radio SAS FM Surabaya dengan penelitian yang bisa dianggap mewakili pendengar lainnya. Cara seperti ini disebut dengan Purposif Sampling. ${ }^{20}$ Kriteria yang dimaksud yaitu: Berusia 20 tahun ke atas., Sering mendengarkan radio 
SAS FM dan Pernah bergabung dalam program "Ngaji Fiqih Kontemporer" dan "Tadarus Keluarga" melalui SMS ataupun telepon

Teknik dokumentasi digunakan untuk mengumpulkan data dari sumber non insani. Sumber ini terdiri dari dokumen dan rekaman. Rekaman berarti setiap tulisan atau pernyataan yang dipersiapkan oleh atau untuk individual atau organisasi dengan tujuan membuktikan adanya suatu peristiwa.

Teknik ini digunakan oleh peneliti untuk mengumpulkan data yang menjelaskan mengenai penyusunan program radio SAS FM, format acara, data kepengurusan radio SAS FM, dan data pendengar yang bergabung di program "Ngaji Fiqih Kontemporer" dan "Tadarus Keluarga", serta dokumen-dokumen lain yang terkait dalam penelitian ini.

\section{Teknik Pengumpulan Data}

\section{1) Interview}

Interview (wawancara) merupakan alat pengumpulan data yang sangat penting dalam penelitian kualitatif, yang melibatkan manusia sebagai subjek (pelaku, aktor) sehubungan dengan realitas atau gejala yang dipilih untuk diteliti. Dalam penelitian ini, peneliti memilih menggunakan metode wawancara informal, yaitu sebuah wawancara yang menunjuk pada kecenderungan sifat terbuka dan tidak terstruktur sehingga seperti percakapan. Pertanyaanpertanyaan mengalir secara spontan seiring dengan berkembangnya konteks dan situasi wawancara dan segala sesuatunya terasa sangat luwes (flexible).

\section{2) Observasi}

Observasi merupakan salah satu teknik pengumpulan data yang digunakan dalam penelitian kualitatif. Dengan menggunakan observasi akan lebih baik hasilnya, karena peneliti akan melaksanakan penelitian secara langsung kedalam obyek penelitian dengan cara berpartisipasi dan ikut serta kedalam kegiatan, disini peneliti ikut membaur dan masuk kedalam sebagai kru radio SAS FM dan juga pendengar program "Ngaji Fiqih Kontemporer" dan "Tadarus Keluarga", untuk memperoleh data yang selengkap-lengkapnya dan data yang dihimpun dapat terjaga kevalidanya.

Sesuai petunjuk dari Lindlof, maka peneliti melakukan sebuah observasi sebagaimana berikut $:^{21}$ (1) Engages the phenomenon for prolonged period of time (sustained), Peneliti mengamati fenomena yang terjadi untuk waktu yang lama dan terus menerus. Dalam hal ini peneliti telah mengikuti kegiatan tersebut serta berbaur dengan kru radio SAS FM dalam kurun waktu 2 bulan. (2) Makes self-conscious and full, clearly expressed notations of how the observing is done (explicit), Rekaman wawancara yang merupakan data otentik dari peneliti mengenai pandangan, penilaian, keinginan dan perasaan-perasaan dari dari fihak radio SAS FM dan juga pendengar radio SAS FM (3) Goes about the observing activity in an alert manner that allows for tactical improvisation (methodological), Peneliti terus menerus melakukan pengamatan secara seksama sambil berimprovisasi, mengatasi persoalan yang ditemui, namun tetap berpegang pada strategi-strategi yang telah ditetapkan untuk mencapai tujuan penelitian (4) Impact attention to object in wats that are in some sense standardized, yet individually trainer (observing) Peneliti senantiasa menyadari posisinya sebagai peneliti, hal ini dilakukan agar dapat bekerja secara objektif, tidak menaruh kepentingan apapun dan dapat meneliti sesuai standard, tetapi tetap berimprovisasi bahkan berapresiasi tertentu (5) Textually construct and edits the observing (paraphrasing)(6) Embeds the observing in the interdependencies of place, actors and activities (sosial situations) (7) Differentiates the background elements of social situations that inform the object on which observing is focused (in relation to their occurring contexts) 


\section{3) Dokumentasi}

Dalam teknik dokumentasi ini digunakan oleh peneliti untuk mengumpulkan data yang menjelaskan mengenai penyusunan program siaran radio SAS FM, format acara serta data kepengurusan radio SAS FM. Dan peneliti juga mengumpulkan data yang menjelaskan mengenai pendengar program "Ngaji Fiqih Kontemporer" dan "Tadarus Keluarga" serta dokumen lain yang berhubungan dengan masalah penelitian yang akan dapat membantu pengumpulan data dalam penelitian.

\section{4) Teknik Analisis Data}

Menangkap fenomena. Peneliti mengumpulkan data-data mengenai strategi dakwah program radio SAS FM Surabaya yang terdiri dari beberapa program dan memiliki program unggulan "Ngaji Fiqih Kontemporer" dan "Tadarus Keluarga" terlihat dari banyaknya pendengar yang bergabung melalui telepon, SMS dan juga streaming.

Mengupayakan validitas dan realiabilitas, dengan wawancara langsung yang dilakukan oleh peneliti pada subjek penelitian dan pihak-pihak yang berkaitan langsung dengan penelitian, data dapat dipastikan valid dan sesuai dengan realitas.

Menganalisisnya dengan memilah-milah dan membuat kategori-kategori atau tema-tema tertentu. Setelah data terkumpul, maka peneliti memilah-milahnya sesuai dengan fokus penelitian agar tercapai tujuan penelitian ini.

Melakukan reduksi data, diartikan sebagai proses pemilihan, pemusatan, perhatian pada penyederhanaan berbagai data yang ada. Agar peneliti lebih mudah dalam mencapai tujuan penelitian.

Memberikan makna-makna atau mengemukakan interprestasi-interprestasi tertentu dengan mengacu pada pandangan-pandangan teoritik tertentu. Dalam hal ini, peneliti memfokuskan pada teori strategi program dan baru kemudian peneliti menarik kesimpulan-kesimpulan

\section{5) Teknik Keabsahan Data}

Tringulasi diartikan sebagai teknik pengumpulan data yang bersifat menggabungkan dari berbagai teknik pengumpulan data dan sumber data yang telah ada. Bila peneliti melakukan pengumpulan data dengan tringulasi, maka sebenarnya peneliti mengumpulkan data yang sekaligus menguji kredibilitas data, yaitu mengecek kredibilitas data dengan berbagai teknik pengumpulan data dan berbagai sumber data. ${ }^{22}$ hal ini dapat dicapai dengan jalan : a) Membandingkan data hasil pengamatan dengan data hasil wawancara. b) Membandingkan apa yang dikatakan orang di depan umum dengan apa yang dilakukan secara pribadi. c) Membandingkan apa yang dikatakan orang-orang tentang situasi penelitian dengan apa yang dikatakan sepanjang waktu. d) Membandingkan keadaan dan perspektif seseorang dengan berbagai pendapat dan pendangan orang seperti rakyat biasa, mahasiswa, orang berada serta orang pemerintah. e) Membandingkan hasil wawancara dengan isi suatu dokumen yang berkaitan.

Teknik keabsahan data tringulasi digunakan untuk mendapatkan hasil dari penelitian yang sebenarnya dengan data yang sesuai dilapangan. Hasil dari wawancara akan dibandingkan dengan dokumen yang berkaitan, tujuannya adalah untuk memastikan sesuai atau tidaknya dengan dokumen. 


\section{Penyajian dan Analisis Data}

\section{A. Sejarah Singkat Radio SAS FM}

Radio SAS FM adalah salah satu radio swasta di Surabaya yang memiliki slogan Radio Inspirasi Muslim Sejuk Bermakna dan merupakan radio swasta dengan format siaran secara umum terdiri dari program news, music, knowledge, inspiration, motivation. Radio SAS FM berlokasi di komplek Masjid Nasional al-Akbar Jl. MAS Timur 1 Pagesangan Surabaya.

Radio SAS FM berada dibawah naungan PT Radio Media Assalam yang berlokasi di Jl. Margorejo Indah A. 509 Surabaya. Radio SAS FM pertama kali siaran percobaan pada tanggal 17 Agustus 2008 (Ahad, 14 Syaban $1429 \mathrm{H}$ ). ${ }^{23}$

Berada di kompleks masjid Nasional al-Akbar Surabaya, radio SAS FM merupakan radio yang selalu mensinergikan program-programnya dengan masjid Nasional al-Akbar Surabaya. Kehadiran radio SAS FM merupakan penyalur dakwah yang ada di masjid Nasional agar bisa sampai meluas ke umat muslim khususnya di wilayah Surabaya dan sekitarnya.

Memiliki visi sebagai media pengembangan syiar, pendidikan, ekonomi, dan sosial budaya menuju masyarakat yang berakhlak karimah dengan mengedepankan aspek informasi yang menyejukkan dan memberi nilai demi perbaikan umat.

Serta memiliki misi, a) Pengembangan dakwah dan syiar Islam b) Pengembangan pendidikan c) Pengembangan sosial budaya d) Pengembangan ekonomi dan bisnis.

\section{B. Penyajian Data}

Radio SAS FM baru berusia enam tahun pada 17 Agustus 2014. Perjuangan dakwah dan menjadikan Masjid Nasional al-Akbar Surabaya sebagai pusat dakwah, merupakan bukti bahwa tidak ada lagi pembatas ruang bagi siapa saja yang ingin mendapatkan inspirasi dan ilmu agama Islam.

Didik Madani selaku station manajer mengatakan bahwa radio SAS FM merupakan radio yang ingin menjadikan radio masjid penuh keberkahan bagi umat Muslim:

"Radio SAS FM ini lahir pada tanggal 17 Agustus 2008 atau 14 Sya'ban 1429 hijriyah. Baru berusia enam tahun, kita disini terus belajar, berus berbenah agar syiar SAS FM ini dapat meluas kemana saja. Dan saat ini radio SAS FM bisa dikatakan sebagai radio masjid. Semua tahu bahwa SAS FM ini lokasinya kan berada di masjid Nasional al-Akbar Surabaya, jadi semua informasi dan kegiatan kajian wajib kita siarkan. Pendengar ingin tahu info masjid ya di SAS FM harus tahu. Karena setiap hari telfon berdering maunya ke UPT masjid ternyata nyambungnya d SAS FM untuk tanya informasi kajian, penceramah dan yang lainnya yang berkenaan dengan masjid al-Akbar, SAS FM wajib menyiarkan. Dan harapan kami di radio SAS FM ini semoga ini bisa menjadi berkah bagi kita semua. ,24

Dari hasil wawancara yang telah dilakukan, peneliti dapat mengetahui bahwasannya konsep awal terbentuknya radio SAS FM Surabaya ini berawal dari ingin menyalurkan dan memperluas kegiatan dakwah yang ada pada Masjid Nasional al-Akbar Surabaya agar dapat di dengar, diketahui oleh seluruh masyarakat khususnya umat muslim. Radio SAS FM merupakan radio masjid, karena setiap kegiatan, kajian dan adzan lima waktu dari Masjid Nasional al-Akbar selalu disiarkan oleh radio SAS FM. Sehingga segala informasi yang ada di Masjid al-Akbar seluruh kru radio SAS FM harus mengetahuinya. Ini yang menyabebkan ada sinergi yang tidak bisa dipisahkan antara Masjid Nasional al-Akbar Surabaya dengan radio SAS FM. Radio SAS FM Surabaya beberapa kali pernah bergati frekwensi mulai 90,5 FM, 102,3 FM, 97,2 FM dan saat ini 
107,5 FM. Selain berganti beberapa kali frekwensi, radio SAS FM juga beberapa kali berganti segmentasi tanpa meninggalkan niatan awal sebagai media dakwah.

Dari hasil wawancara yang telah dilakukan, peneliti dapat mengetahui bahwa strategi dakwah pada program "Ngaji Fiqih Kontemporer" dan "Tadarus Keluarga" adalah terletak pada Dai-nya, yakni narasumber yang menyampaikan. Program "Ngaji Fiqih Kontemporer" terdiri dari dua narasumber, Prof. DR. KH. Ahmad Zahro dan Prof. DR. KH. Ahmad Faishol Haq. Keduanya merupakan guru besar Ilmu Fiqih. Sedangkan program "Tadarus Keluarga" narasumbernya adalah Ustad Yahya Aziz, M.Ag dan beliau juga penulis buku "Manis Pahit Taubatnya Peselingkuh" yang terinspirasi dari masalah-masalah perdengar yang bergabung. Strategi berikutnya terletak pada waktunya siang hari, dipilih karena sangat efektif dan menjadi pembeda dengan program kajian di radio lain yang kebanyakan pagi hari. Strategi dakwah juga pada kemasan program. Program "Ngaji Fiqih Kontemporer" tidak bertopik, melainkan langsung pendengar bertanya Dai atau narasumber menjawab. Sedangkan "Tadarus Keluarga" topik terkini tentang masalah keluarga yang dipilih dan juga membahas buku yang di tulis narasumbernya. Dengan strategi inilah dapat menarik pengiklan untuk memasang iklan di radio SAS FM.

Dari hasil wawancara yang telah dilakukan dengan beberapa pendengar, peneliti dapat mengetahui bahwasannya respon pendengar mengenai program "Ngaji Fiqih Kontemporer" dan "Tadarus Keluarga" sangat bagus, yang terletak pada Dai atau narasumber yang sangat kompetain dalam menjawab segala pertanyaan dari pendengar. Pertannyaan yang sering ditanyakan oleh pendengar dalam program "Ngaji Fiqih Kontemporer" masalah ibadah dan kehidupan sehari-hari. Sedangkan program "Tadarus Keluarga" pertanyaan yang sering ditanyakan tentang masalah perselingkuhan dan masalah keluarga yang lainnya. Harapan pendengar semoga ada program off air dari dua program unggulan radio SAS FM

\section{Kesimpulan}

Dari pembahasan-pembahasan di atas, dapat peneliti simpulkan bahwa strategi dahwah sangat dibutuhkan oleh kegiatan dakwah untuk mendapatkan hasil yang maksimal dalam berdakwah. Dakwah bukan hanya seorang Dai menyampaikan pesan dakwah melalui mimbar, namun dakwah juga dapat dilakukan melalui media radio. Hampir semua masyarakat memiliki radio yang harganya murah namun manfaatnya banyak. Radio juga didengarkan bagi pendengar yang berkendara dengan mobil untuk mendapatkan informasi.

Saat ini telah banyak stasiun radio swasta yang memiliki format dan segmentasi berbeda-beda. Dan kini radio swasta dengan format Islami juga berkembang. Radio Islami bukan lagi dikatakan radio komunitas yang terbatas untuk memperlua jangkauan siaran dan program yang disiarkan.

Radio Suara Akbar Surabaya (SAS) FM, salah satu radio swasta Islami yang berada di kompleks Masjid Nasional al-Akbar Surabaya hadir untuk menjadi media dakwah yang mengsinergikan programnya dengan masjid Nasional al-Akbar Surabaya. Segala kegiatan yang ada di Masjid Nasional al-Akbar Surabaya selalu disiarkan oleh radio SAS FM. Dapat dikatakan bahwa radio SAS FM merupakan radio masjid karena selalu menyiarkan kajian dan program yang berkenaan dengan Masjid Nasional al-Akbar Surabaya.

Radio SAS FM memiliki dua program unggulan yakni program "Ngaji Fiqih Kontemporer" dan "Tadarus Keluarga". Dikatakan unggulan karena banyak pendengar yang bergabung pada kedua program tersebut, baik melalui telepon, SMS, facebook, tweeter, dan streaming. Program ini memiliki strategi dakwah yang berbeda dengan program yang lainnya. Strategi dakwah yang pertama terletak pada Dai atau narasumber yang kompetain yang mengisi kedua program tersebut. Program "Ngaji Fiqih Kontemporer" narasumbernya Prof. Ahmad Zahro dan Prof. Ahmad Faishol Haq. Beliau berdua merupakan guru besar Ilmu Fiqih UIN Sunan Ampel Surabaya. Sedangan program "Tadarus Keluarga" narasumbernya ustad Yahya Aziz, pengarang buku "Manis Pahit Taubatnya Peselingkuh" yang terinspirasi dari masalah-masalah perdengar yang bergabung. Strategi berikutnya terletak pada waktunya siang hari, dipilih karena sangat efektif dan menjadi pembeda dengan program kajian di radio lain yang kebanyakan pagi hari. Strategi 
dakwah juga pada kemasan program. Program "Ngaji Fiqih Kontemporer" tidak bertopik, melainkan langsung pendengar bertanya Dai atau narasumber menjawab. Sedangkan "Tadarus Keluarga" topik terkini tentang masalah keluarga yang dipilih dan juga membahas buku yang di tulis narasumbernya. Dengan strategi inilah dapat menarik pengiklan untuk memasang iklan di radio SAS FM.

Sedangkan respon pendengar mengenai program "Ngaji Fiqih Kontemporer" dan "Tadarus Keluarga" sangat bagus, yang terletak pada Dai atau narasumber yang sangat kompetain dalam menjawab segala pertanyaan dari pendengar. Pertannyaan yang sering ditanyakan oleh pendengar dalam program "Ngaji Fiqih Kontemporer" masalah ibadah dan kehidupan sehari-hari. Sedangkan program "Tadarus Keluarga" pertanyaan yang sering ditanyakan tentang masalah perselingkuhan dan masalah keluarga yang lainnya. Harapan pendengar semoga ada program off air dari dua program unggulan radio SAS FM

\section{DAFTAR PUSTAKA}

Amin, Samsul Munir, 2008. Rekonstruksi Pemikiran Dakwah Islam, Jakarta: Amzah.

Arikunto, Suharsimi, 1998. Prosedur Penelitian, Yogyakarta: Rineka Cipta.

Aziz, Moh. Ali, 2009. Ilmu Dakwah Edisi Revisi, Jakarta: Kencana , 2004. Ilmu Dakwah, Jakarta: Kencana,

Bogdan, Robert, dan Steven J. Tailor, 1975. Introduction to Qualitative Research Methods: A Phenomenological Approach to The Sosial Sciens, New York, John Wiley \& Sons.

Danim, Sudarwan, 2002. Menjadi Peneliti Kualitatif , Bandung: Pustaka Setia,

Effendy, Onong Uchjana, 1993. Dinamika Komunikasi, Bandung: Remaja Rosdakarya

Rosdakarya. Ilmu Komunikasi Teori dan Praktek, 2004. Bandung: PT. Remaja 1991. Radio Siaran Teori dan Praktek, Bandung: Mandar Maju. 2003. Ilmu teori dan Filsafat Komunikasi, Bandung: Citra Aditya Bakti

Head, Sydney W., Cristopher H. Sterling, 1982. Broadcasting In America; a Survey of Television, Radio, and New Technologies, Boston: Houghton Mifflin Company.

Herford, Peter, 2000. So You Want To Run a Tv Station, Loan Fund: Media Development.

K., Maxine, dan Robert M. Reed, 1986. Career Opportunities In Television, Cable and Video, $2^{\text {nd }}$ Edition, New York: Facts on File Publication.

Kusnawan, Aep, 2004. Komunikasi dan Penyiaran Islam, Bandung: Benang Merah Press.

Lindlof, Thomas, 1995. Qualitative Communication Research Methods, Thousand Oaks, London: Sage Publication.

Masduki, 2001. Jurnalistik Radio, Yogyakarta: LkiS.

Moleong, Lexy J., 1996. Metodologi Penelitian Kualitatif, Bandung; Remaja Rosdakarya. , 2008. Metode Penelitian Kualitatif, cet. 25, Bandung: Remaja Rosdakarya.

Morissan, 2008. Manajemen Media Penyiaran, Jakarta: Kencana.

Munir, M. dan Wahyu Ilaihi, 2006. Manajemen Dakwah, Jakarta: Kencana.

Natsir. M, 1984. Fiqhud Dakwah, Semarang: Ramadhani.

Ningrum, Fatmasari, 2007. Sukses Menjadi Penyiar, Jakarta: Swadaya. 
Patton, Michael Quinn, 2002. Qualitative Research \& Evaluation Methods $3^{\text {rd }}$ ed., Thousand Oaks: Sage Publication.

Pawito, 2007. Penelitian Komunikasi, Yogyakarta: Lkis Pelangi Aksara,

PB, Triton, 2008. Marketing Strategic Meningkatkan Pangsa Pasar dan Daya Saing, Yogyakarta: Tugu Publisher.

Prayudha, Harley, Radio: 2004. Suatu Pengantar Untuk Wacana dan Praktek penyiaran, Malang: Bayumedia Publishing.

Pringle, Peter K., Michael F Star, William E McCavit, 1991. Electronic Media Management, Boston: Focal Press.

Punch, Keith, 1998. Introduction to Social Research: Quantitative \& Qualitative Approaches, London: Sage Publications.

Rafi'udin dan Maman Abdul Djaelani, 2004. Prinsip dan Strategi Dakwah, Bandung: CV. Pustaka Setia.

Rakhmat, Jalaluddin, 2005. Metode Penelitian Komunikasi, Dilengkapi Contoh Analisis Statistik, Bandung: Rosdakarya.

Rosdakarya. 2000. Metode Penelitian Komunikasi, Cet. 8, Bandung: Remaja

Romli, Asep Samsul M., 2004. Broadcast Journalism, Bandung: Nuansa.

Sugiyono, 2005. Memahami Penelitian Kualitatif, Bandung: Alfabeta.

Syam, Nur, 2003. Filsafat Dakwah Pemahaman Fisiologis tentang Ilmu Dakwah, Surabaya: Jenggala Pustaka Utama:

Syam, Nur, 1991. Metodologi Penelitian Ilmu Dakwah, Solo: CV Romadhoni,

Syukir, Asmuni, 1983. Dasar-Dasar Strategi Dakwah Islam, Surabaya: al-Ikhlas,

Tulaeka, Hamzah, 1993. Pengantar Ilmu Dakwah, Surabaya: Indah Offset,

Wahyudi, JB., 1996. Dasar-dasar Jurnalistik Radio dan Televisi, Jakarta: Pustaka Utama Grafiti 